\title{
Review
}

Fetal Diagnosis

and Therapy

\section{Assessment of Fetal Cardiac Function Using Tissue Doppler Techniques}

\author{
Montse Comas $^{\text {a }}$ Fatima Crispi $^{\mathrm{b}}$ \\ a Servei de Ginecologia i Obstetrícia, Corporació Sanitària Parc Taulí, Sabadell, and bepartment of Maternal-Fetal \\ Medicine, Institut Clínic de Ginecologia, Obstetrícia i Neonatologia (ICGON), Hospital Clinic, Fetal and Perinatal \\ Medicine Research Group, Institut d'Investigacions Biomèdiques August Pi i Sunyer (IDIBAPS), University of \\ Barcelona, and Centro de Investigación Biomédica en Red de Enfermedades Raras (CIBER-ER), Barcelona, Spain
}

\section{Key Words}

Tissue Doppler imaging • Cardiac function •

Echocardiography $\cdot$ Myocardial velocities $\cdot$ Strain

\begin{abstract}
Objective: Tissue Doppler echocardiography is being increasingly used in fetal medicine as a clinical and research tool. The objective of this study was to review the current status of tissue Doppler imaging (TDI) techniques applied to the fetus. Methods: Fetal cardiac function was evaluated using spectral and color TDI modes in normal fetuses and in several clinical conditions. Results: Annular peak velocities and their ratios as well as the myocardial performance index were evaluated using spectral TDI, and changes throughout gestation were described. Color TDI has several limitations in fetal life, particularly the use of low frame rates with current methods of acquisition and the lack of normal references for deformation parameters. Conclusions: Despite its limitations, TDI is a sensitive and promising method to evaluate fetal cardiac function.

Copyright $\odot 2012$ S. Karger AG, Basel
\end{abstract}

\section{Background}

Tissue Doppler imaging (TDI) is a consolidated and reproducible echocardiographic technique that was first described in 1989 [1] and permits accurate and direct quantitative assessment of myocardial motion. In adult echocardiography, this technique is useful in the early identification of subtle cardiac dysfunction in preclinical stages $[2,3]$ and as a prognostic tool in major cardiac diseases, such as heart failure, acute myocardial infarction, and hypertension. In these situations, peak annular velocities (PAV), the transmitral-to-mitral annular diastolic velocity ratio (E/E'), and intraventricular dyssynchrony have been shown to predict mortality and cardiovascular events [4]. Due to these properties, in fetal life, TDI could constitute a more sensitive tool than standard methods to detect the presence of cardiac dysfunction. Recently, several studies have applied and evaluated this echocardiographic technique in fetuses.

While conventional echocardiographic techniques are based on blood flow, TDI uses frequency shifts of ultrasound waves to calculate myocardial velocity, which is characterized by a lower velocity and a higher amplitude [5]. Because of these characteristics, TDI assessment has

\section{KARGER \\ Fax +4161306 1234 \\ E-Mail karger@karger.ch}

www.karger.com
(C) 2012 S. Karger AG, Basel

$1015-3837 / 12 / 0322-0030 \$ 38.00 / 0$

Accessible online at:

www.karger.com/fdt
Fatima Crispi

Department of Maternal-Fetal Medicine (ICGON)

Hospital Clínic, Universitat de Barcelona, Sabino de Arana 1

ES-08028 Barcelona (Spain)

Tel. +34 932279 333, E-Mail fcrispi@ @linic.ub.es 
Table 1. Web links to commercially available tissue Doppler echocardiography

Siemens ACUSON Antares ${ }^{\mathrm{TM}}$

Siemens Sequoia

General Electric Vivid-7

Toshiba Aplio XG and Aplio MX

Philips HD11 XE

Aloka ProSound Alpha 10
http://www.medical.siemens.com/siemens/en_INT/gg_us_FBAs/files/brochures/Acuson/ Antares_Cardiac.pdf

http://www.SequoiaUltrasound.com/pdf/sequoiaultrasound.com/Sequoia_512_Data_Sheet.pdf http://www.vivid7ultrasound.com/pdf/vivid7ultrasound.com/Vivid_7_2D_Strain_Brochure.pdf http://www.medical.toshiba.com/products/ul/aplioxg/cardiology-applications.php http://www.healthcare.philips.com/in_en/products/ultrasound/systems/hd11xe/index.wpd http://www.aloka.com/products/view_system.asp?id=12 a lower load dependency than standard Doppler techniques. Table 1 lists the available echocardiography systems with tissue Doppler. TDI can be performed in spectral and color-coded modes.

\section{Spectral TDI}

In spectral TDI (S-TDI), Doppler information is sampled from a small sample volume (defined in $2 \mathrm{D}$ or color image) and presented on a timeline. Sampling is performed online though a preset system feature which adjusts the scale and velocity, similar to pulsed Doppler of blood flow. This technique is especially appropriate for measuring long-axis ventricular motion because the longitudinal fibers are more parallel to the ultrasound beam in the apical and basal views.

\section{Technique and Measurements}

In an apical or basal four-chamber view, the image is enlarged, the 2D scan area is reduced, and a sample volume between 2 and $4 \mathrm{~mm}$ is placed in the basal part of the ventricle or annulus. The insonation ultrasound beam is maintained at an angle of $<30^{\circ}$ to the ventricular wall or intraventricular septum. No angle correction should be applied. The velocity of myocardial movement toward the Doppler cursor is displayed as a spectrum [6] and waveforms are obtained (minimum 3) (fig. 1).

\section{Measurements}

The main outcome of S-TDI is PAV (fig. 1): (1) E' or Ea, early diastolic annular relaxation velocity, (2) A' or Aa, annular velocity during auricular contraction, and (3) S' or Sa, annular velocity during ventricular systole. Peak velocities are usually assessed in the valve annulus where long-axis ventricular motion of the myocardium is displayed as a measurement of global cardiac function. Regional function can be also assessed by evaluating myocardial peak velocities in any area on the myocardium.

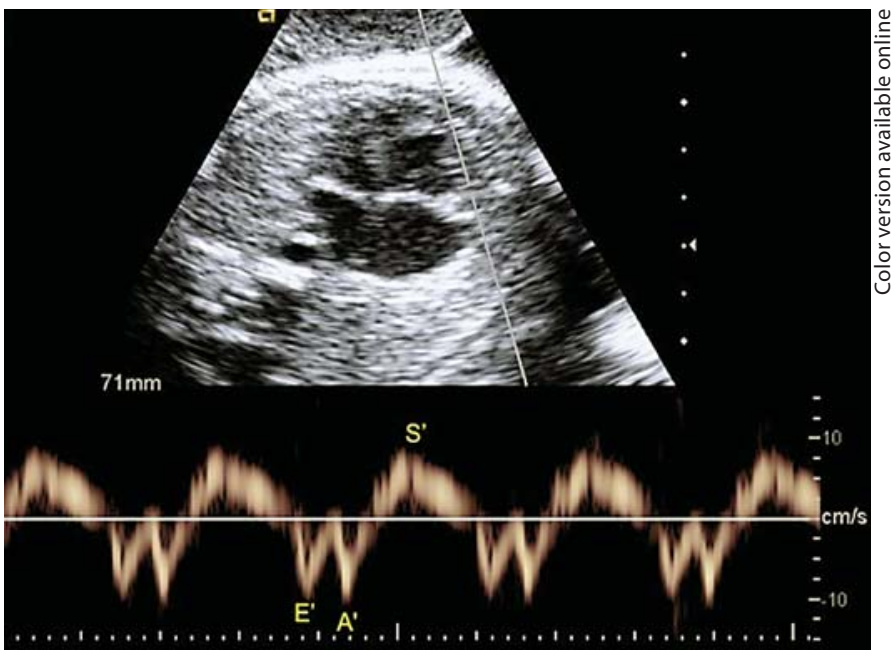

Fig. 1. Example of PAV obtained by spectral tissue Doppler in the right annulus. The sample volume is placed in the right annulus just below the tricuspid valve with an insonation angle of the ultrasound beam of $\angle 30^{\circ}$ to the orientation of the ventricular wall. A tissue Doppler spectral waveform is displayed and PAV are obtained. $\mathrm{E}^{\prime}=$ Annular velocity in early diastole; $\mathrm{A}^{\prime}$ = annular velocity during atrial contraction; $S^{\prime}=$ annular velocity in systole.

Furthermore, several time periods can also be calculated to obtain the myocardial performance index (MPI'): isovolumic contraction time (ICT'), ejection time (ET'), and isovolumic relaxation time (IRT'). MPI' can be calculated as (ICT' + IRT')/ET'.

\section{Feasibility and Reproducibility}

TDI has been shown to be feasible in fetuses [7-9]. The first to show that TDI was technically possible in human fetuses were Harada et al. [7], who evaluated a group of 30 fetuses between 19 and 38 weeks of gestation using STDI. S-TDI evaluation was successfully performed in all fetuses and the tissue Doppler wave pattern was described, consisting of E', A', and S'. Subsequent studies $[10-12]$ corroborated the high feasibility of this technique 
(79-97\% of the fetuses), being better at the right annulus than the left side or IVS. Several studies have evaluated the reliability of S-TDI in fetuses of at least 14 weeks and have shown acceptable reproducibility $[7,10,11,13]$. Chan et al. [10] reported that reliability ranged from 0.91 to 0.97 using the intraclass correlation coefficient (ICC). Another recent study [13] showed similar, although lower, ICC values ranging from 0.66 to 0.88 . Gardiner et al. [11] reported suboptimal interobserver reliability for PAV, which was explained by the presence of a small number of high outliers.

The reliability of left and right MPI' has also been evaluated by two recent studies $[14,15]$ reporting ICC values ranging between 0.70 and 0.94 .

\section{Limitations}

Although fetal position and movements, the small fetal heart size, the high fetal heart rate, restricted physical access to the fetus, and the relatively low resolution of ultrasound equipment may limit the acquisition of S-TDI, several recent works have demonstrated that S-TDI is feasible and reproducible in most fetuses even from early on in the second trimester of pregnancy [7, 10-14]. The main disadvantage of this technique is that it only provides information on velocities [not strain (S) or strain rate (SR)] from one region of the heart at a time and does not allow multiple regions to be studied simultaneously.

\section{Color TDI}

In color TDI (C-TDI), velocimetry is presented as a color-coded overlay on top of a B-mode image. To perform C-TDI analysis, a cardiac cine loop with a high frame rate is acquired and the evaluation of TDI-derived parameters is performed offline.

\section{Technique}

C-TDI video clips are obtained during fetal quiescence with the ultrasound beam parallel to the region on interest (usually the septum or myocardial free walls in an apical or baseline four-chamber view). If needed, a sector tilt can be used to ensure that the angle between the probe and myocardial motion is $<15^{\circ}$.

While recording the loop, the $2 \mathrm{D}$ scan area and the TDI color box should be kept as small as possible to obtain the highest number of frames per second (fps). It is critical to acquire images at a high frame rate ( $>200 \mathrm{fps}$ ). The color gain must be adjusted to avoid aliasing. For each acquisition, at least $5 \mathrm{~s}$ of noncompressed data should be recorded. Analysis of TDI-derived parameters is performed offline. The velocity of myocardial movement toward the transducer is obtained for each pixel of the image. A color-coded representation of myocardial velocities, S, and SR is displayed offline (fig. 2). At least 3-5 cardiac cycles should be obtained with similar characteristics (slope $<30^{\circ}$ ) to confirm good-quality acquisition. An advantage of C-TDI is that multiple segments can be evaluated in a single view, thus allowing segmental information of cardiac function to be obtained. Furthermore, deformation (S and SR) parameters can be also assessed.

\section{Measurements}

Apart from myocardial velocities, deformation indices such as S and SR can be evaluated offline using C-TDI. S represents the lengthening change of a myocardial segment from its original length. SR consists of the change of $\mathrm{S}$ during time. Velocity measurements cannot differentiate between active and passive motion related to translation or tethering of a myocardial segment. In contrast, deformation analysis allows discrimination between active and passive myocardial tissue movement [15] and could be more sensitive than myocardial velocities for noninvasive assessment of ventricular function.

\section{Feasibility and Reproducibility}

The reliability of C-TDI has been evaluated in fetuses. However, several limitations such as the frame rate and electrocardiogram (ECG) co-registration should be taken into account before drawing conclusions. The first report of C-TDI in fetal life was by Paladini et al. [16], who described high feasibility (84\%) and reproducibility. However, these data were based on very low temporal resolution (20-40 fps), which strongly limits the validity of these findings. Subsequently, Nii et al. [17] obtained accurate TDI recordings in 96,96 , and $93 \%$ of cases in the left annulus, right annulus, and IVS, respectively, and also reported a good intra- and interobserver reproducibility of PAV measurements. In another study, Perles et al. [18] evaluated 98 fetuses by C-TDI and measurement of PAV, and S and SR was achieved in all cases. Deformation parameters such as SR were evaluated in four fetuses by Larsen et al. [19]. These authors highlighted the importance of collecting cardiac motion information with high frame rates (over $200 \mathrm{fps}$ ), which allows the fast events of the fetal heart to be correctly analyzed. A recent article by Crispi et al. [20] reported acceptable feasibility and reproducibility using a dummy ECG for the first time by manually indicating the onset of each cardiac cycle in 


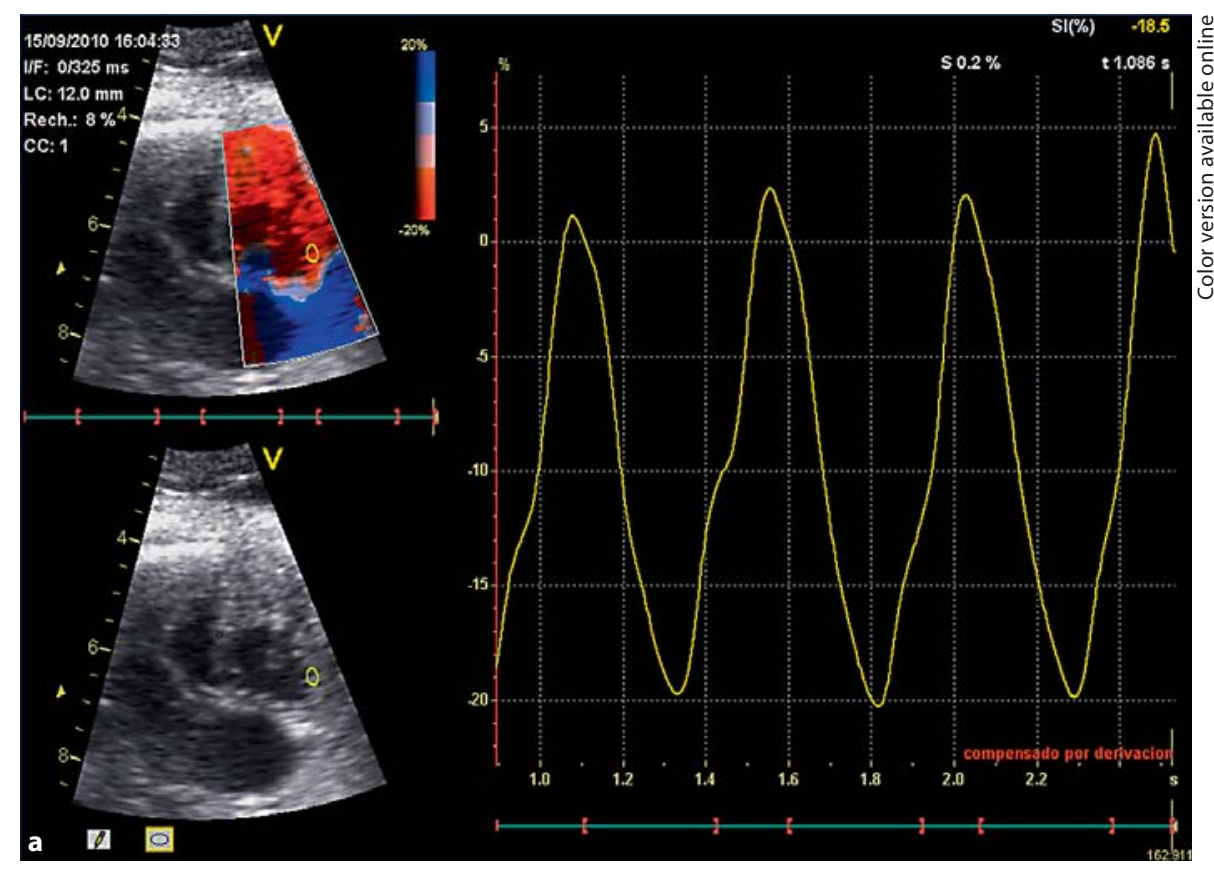

Fig. 2. Example of measurement of $S$ (a) and SR (b) by color tissue Doppler. A fourchamber view with the right free wall aligned parallel to the Doppler beam is used and color tissue Doppler is superimposed. Offline analysis is performed displaying the S and SR of the right basal free wall.

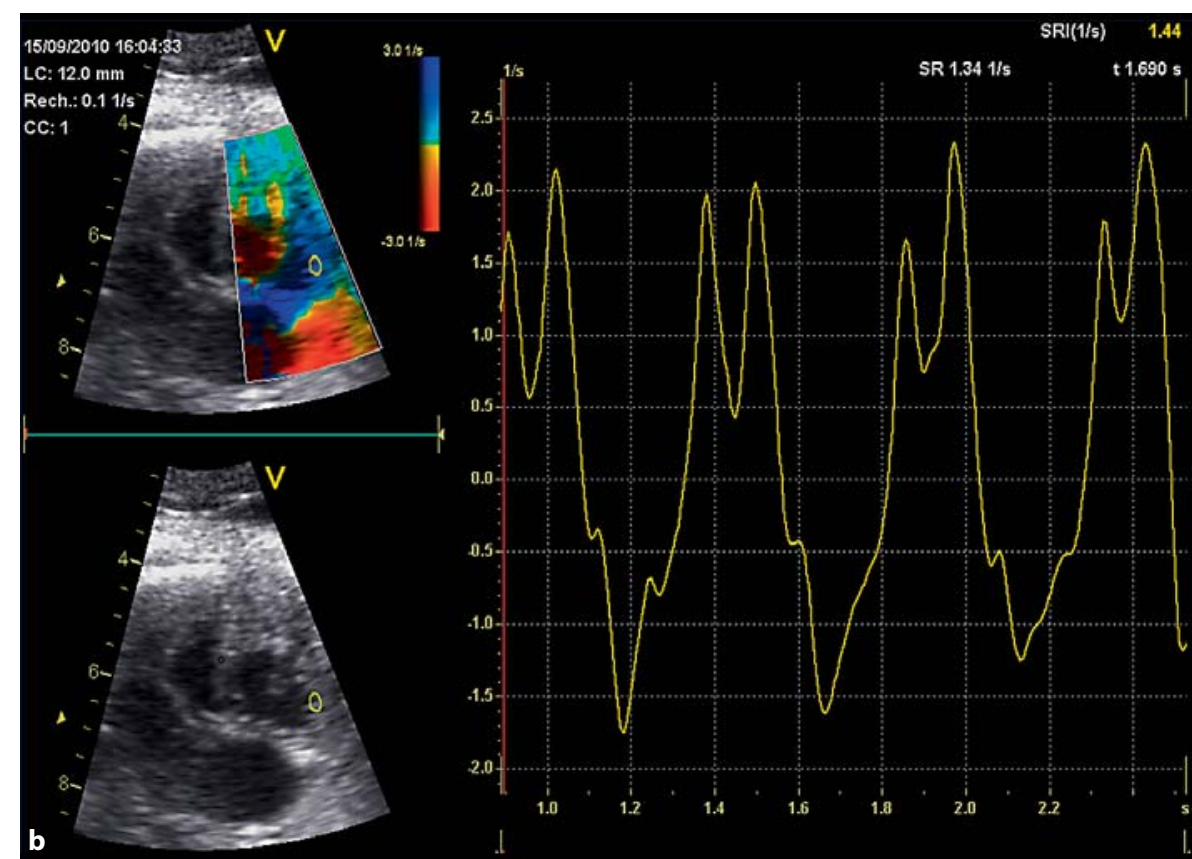

the $2 \mathrm{D}$ clip based on valve motion. Feasibility and reproducibility during the first trimester of gestation have not yet been described.

\section{Limitations}

The use of C-TDI has several limitations in fetal life compared with the use of this technique in adults, which are listed below:

Tissue Doppler Techniques and Assessment of Fetal Cardiac Function
(1) Fetal position: during echocardiographic examination, the fetal position can vary, which sometimes does not allow a perfect apical four-chamber view to be obtained. Obtaining C-TDI recordings with a good angle is crucial to prevent underestimation of variables such as velocities.

(2) Fetal movements: recordings must be acquired during fetal quiescence, avoiding periods of fetal and respira-

Fetal Diagn Ther 2012;32:30-38 
tory movements that could interfere with the TDI algorithm.

(3) Frame rate: a high frame rate is critical to correctly analyze the fast events occurring throughout the cardiac cycle. Frame rates of at least $140 \mathrm{fps}$ are required to adequately analyze myocardial events during each cardiac cycle in adults. Since the heart rate is higher in fetuses than in adults (110-180 beats per min), the temporal resolution permitted by the frame rate may limit this offline analysis. The technical limitations of some initial fetal studies using C-TDI include the use of ultrasound equipment with low TDI frame rates, which can lead to poor temporal resolution and sometimes result in underestimation of time-dependent variables such as velocities, MPI, and SR. Recently, frame rates exceeding $200 \mathrm{fps}$ have become possible using some equipment $[17,20]$.

(4)Co-registration with ECG: in adult cardiology, CTDI evaluation is usually carried out with simultaneous ECG registration to record myocardial events accurately. However, fetal ECG cannot be performed during gestation. The use of virtual fetal ECG has recently been shown to have good reproducibility [20].

(5) Resolution of ultrasound machines: most of the available transducers and equipment used to assess TDI in fetuses (table 1) were designed for adults and have not yet been adapted to obstetric ultrasound, which may limit proper evaluation of the fetal heart due to restricted physical access to the fetus and the small size of the fetal heart. Additionally, myocardial peak velocities are markedly lower in fetuses than in children and adults. Even the lowest available scale size of most ultrasound machines is often too large. In this case, waveforms are often displayed with suboptimal resolution, which may hamper accuracy.

(6)Low peak myocardial velocities: peak velocities obtained by C-TDI are always lower than those obtained by S-TDI, which may limit the accuracy of measurements.

\section{Reference Ranges for Tissue Doppler Parameters during Normal Gestation}

\section{$P A V$ and E'/A' E/E' Ratios}

Reference charts for S-TDI parameters have been reported by several authors, showing similar values. PAV and E'/A' ratios seem to increase throughout gestation while a negative relationship between the $\mathrm{E} / \mathrm{E}$ ' ratio and gestation has been described because of a greater increase in E' than in E [10-12].

For C-TDI, an increase in PAV and E'/A' ratios and a decrease in $\mathrm{E} / \mathrm{E}^{\prime}$ have also been reported in the left and right ventricles and IV septum [17]. Although these findings are consistent with S-TDI, peak velocity measurements were $15-20 \%$ lower than similar peak velocity measurements obtained by instantaneous S-TDI, which was attributed to the averaging at interrogated regions conducted with C-TDI. Accordingly, peak E' and A' were slightly smaller and E/E' was slightly higher when compared with previously published data obtained by S-TDI.

Moreover, differences could also be explained by the use of distinct echocardiographic equipment. The use of different echocardiographic TDI systems has yielded correlated but distinct values for myocardial velocities. Consequently, use of the same echocardiographic equipment during patient follow-up, as well as reference charts, has been recommended [21].

\section{Time Intervals}

MPI' values obtained by S-TDI are generally higher than those obtained by standard pulsed Doppler [14] and have shown a slight tendency to increase with gestational age [12]. In another study, Nii et al. [22] demonstrated the feasibility of C-TDI for measuring fetal atrioventricular time intervals and establishing gestational age reference data, which could be used to assess fetal atrioventricular conduction, particularly in cases of maternal anti-Ro and anti-La antibodies.

\section{$S$ and $S R$}

Characterization of deformation parameters during gestation is still insufficiently known. While some authors suggest that $\mathrm{S}$ and $\mathrm{SR}$ increase with gestational age [23] others argue that these parameters remain stable [18] throughout gestation. Similar discordances have also been described in deformation analysis by $2 \mathrm{D}$ speckle tracking techniques; the first reports using a low frame rate reported no changes in S throughout gestation [24] while recent studies using more appropriate frame rates have demonstrated that $\mathrm{S}$ decreases with gestational age $[25,26]$. Future studies in TDI using acceptable high frame rates to validate these parameters and their reproducibility are needed to study myocardial deformation properties in the fetus. 
Table 2. Summary of most important spectral tissue Doppler studies

\begin{tabular}{|c|c|c|c|c|c|c|c|c|}
\hline Reference & $\begin{array}{l}\text { Echocardio- } \\
\text { graphic system }\end{array}$ & $\begin{array}{l}\text { Sample } \\
\text { size }\end{array}$ & Population & $\begin{array}{l}\text { GA range } \\
\text { weeks }\end{array}$ & $\begin{array}{l}\text { Annular } \\
\text { location }\end{array}$ & Results & $\begin{array}{l}\text { Other new } \\
\text { information }\end{array}$ & Limitations \\
\hline $\begin{array}{l}\text { Harada et } \\
\text { al. [7] (1999) }\end{array}$ & Aloka SSD-2200 & 30 & $\begin{array}{l}\text { Normal } \\
\text { fetuses }\end{array}$ & $19-38$ & $\begin{array}{l}\text { Left, right, } \\
\text { septum }\end{array}$ & $\begin{array}{l}E^{\prime}<A^{\prime}, P A V \text { and } E^{\prime} / A^{\prime} \\
\text { increased with GA } \\
\text { (except for A' and } \\
\text { septal S') }\end{array}$ & $\begin{array}{l}\text { Typical fetal tissue } \\
\text { Doppler wave was } \\
\text { provided }\end{array}$ & Small sample size \\
\hline $\begin{array}{l}\text { Tutscheck et } \\
\text { al. [9] (2003) }\end{array}$ & $\begin{array}{l}\text { Philips ATL HDI } \\
5000\end{array}$ & 77 & $\begin{array}{l}\text { Normal } \\
\text { fetuses }\end{array}$ & $15-40$ & Left, right & $\begin{array}{l}\text { PAV and E'/A' ratios } \\
\text { increased with GA }\end{array}$ & $\begin{array}{l}\text { Cardiac wall motion } \\
\text { was detected by } \\
\text { changing the Doppler } \\
\text { settings but without } \\
\text { specific TDI equipment }\end{array}$ & Small sample size \\
\hline $\begin{array}{l}\text { Aoki et al. } \\
\text { [36] (2004) }\end{array}$ & Aloka SSD-5500 & 43 & $\begin{array}{l}7 \text { heart } \\
\text { failure, } \\
36 \text { controls }\end{array}$ & $16-39$ & Right & $\begin{array}{l}\text { Increased E/E' and } \\
\text { MPI' in fetuses with } \\
\text { heart failure }\end{array}$ & $\begin{array}{l}\text { E/E' and MPI' could be } \\
\text { useful as indicators of } \\
\text { right cardiac } \\
\text { dysfunction }\end{array}$ & $\begin{array}{l}\text { Small sample size } \\
\text { Lack of reference } \\
\text { ranges for MPI' }\end{array}$ \\
\hline $\begin{array}{l}\text { Gardiner et } \\
\text { al. [11] (2006) }\end{array}$ & Sequoia Siemens & 159 & $\begin{array}{l}\text { Normal } \\
\text { fetuses }\end{array}$ & $15-38$ & $\begin{array}{l}\text { Left, right, } \\
\text { septum }\end{array}$ & $\begin{array}{l}\text { PAV increased with GA } \\
\text { (except for left A). } \\
\text { Right PAV were higher } \\
\text { than left PAV }\end{array}$ & $\begin{array}{l}\text { PAV showed similar } \\
\text { gestational rates of } \\
\text { increase in both } \\
\text { ventricles, suggesting } \\
\text { similar maturational } \\
\text { changes }\end{array}$ & $\begin{array}{l}\text { Higher interoperator } \\
\text { variation }\end{array}$ \\
\hline $\begin{array}{l}\text { Hátem et al. } \\
\text { [33] (2008) }\end{array}$ & $\begin{array}{l}\text { Philips HP Sonos } \\
5500\end{array}$ & 62 & $\begin{array}{l}47 \text { diabetes, } \\
15 \text { controls }\end{array}$ & $25-37$ & $\begin{array}{l}\text { Left, right, } \\
\text { septum }\end{array}$ & $\begin{array}{l}\text { Higher PAV and lower } \\
\text { E/E' in the fetuses of } \\
\text { diabetic mothers }\end{array}$ & $\begin{array}{l}\text { No differences between } \\
\text { the fetuses of diabetic } \\
\text { mothers with and } \\
\text { without myocardial } \\
\text { hypertrophy }\end{array}$ & Small sample size \\
\hline $\begin{array}{l}\text { Watanabe et } \\
\text { al. [38] (2009) }\end{array}$ & Aloka SSD-6500 & 56 & $\begin{array}{l}12 \text { IUGR, } \\
6 \text { hydrops, } \\
38 \text { controls }\end{array}$ & $17-38$ & Left, right & $\begin{array}{l}\text { Right PAV were } \\
\text { higher than left PAV. } \\
\text { Lower left S' and higher } \\
\text { left E'/A' in fetuses with } \\
\text { hydrops }\end{array}$ & $\begin{array}{l}\text { Right } S^{\prime} / \text { left } S^{\prime} \text { is a new } \\
\text { index which was higher } \\
\text { in IUGR and lower in } \\
\text { hydrops }\end{array}$ & $\begin{array}{l}\text { Small sample size } \\
\text { Interobserver } \\
\text { variability was not } \\
\text { determined }\end{array}$ \\
\hline $\begin{array}{l}\text { Comas et al. } \\
\text { [13] (2010) }\end{array}$ & Antares Siemens & 75 & $\begin{array}{l}25 \text { IUGR, } 75 \\
\text { controls }\end{array}$ & $26-34$ & $\begin{array}{l}\text { Left, right, } \\
\text { septum }\end{array}$ & $\begin{array}{l}\text { Lower left and right } \\
\text { PAV, higher left E'/A' } \\
\text { and MPI' in early IUGR }\end{array}$ & $\begin{array}{l}\text { Presence of both } \\
\text { systolic and diastolic } \\
\text { cardiac dysfunction in } \\
\text { IUGR, detected by TDI }\end{array}$ & $\begin{array}{l}\text { Small sample size. } \\
\text { Uncertain } \\
\text { correlation with } \\
\text { perinatal and } \\
\text { postnatal } \\
\text { cardiovascular } \\
\text { outcome }\end{array}$ \\
\hline $\begin{array}{l}\text { Comas et al. } \\
\text { [12] (2011) }\end{array}$ & Antares Siemens & 213 & $\begin{array}{l}\text { Normal } \\
\text { fetuses }\end{array}$ & $24-42$ & $\begin{array}{l}\text { Left, right, } \\
\text { septum }\end{array}$ & $\begin{array}{l}\text { PAV and left and right } \\
\text { E'/A' increase with GA. } \\
\text { E/E' decreases with GA }\end{array}$ & $\begin{array}{l}\text { Reference ranges for } \\
\text { MPI' were first } \\
\text { reported. Left MPI' } \\
\text { increased with GA }\end{array}$ & $\begin{array}{l}\text { Information limited } \\
\text { to } 24 \text { weeks onwards }\end{array}$ \\
\hline $\begin{array}{l}\text { Comas et al. } \\
\text { [30] (2011) }\end{array}$ & Antares Siemens & 116 & $\begin{array}{l}58 \text { SGA } \\
58 \text { controls }\end{array}$ & $34-41$ & $\begin{array}{l}\text { Left, right, } \\
\text { septum }\end{array}$ & $\begin{array}{l}\text { Lower right E' and A' } \\
\text { and higher MPI' in } \\
\text { SGA }\end{array}$ & $\begin{array}{l}\text { Presence of subclinical } \\
\text { cardiac dysfunction in } \\
\text { SGA with normal } \\
\text { umbilical artery, } \\
\text { detected by TDI }\end{array}$ & $\begin{array}{l}\text { Significant changes } \\
\text { only in the right } \\
\text { ventricle that could } \\
\text { be explained for } \\
\text { higher PAV or better } \\
\text { Doppler insonation }\end{array}$ \\
\hline
\end{tabular}

GA = Gestational age; E' = early diastolic annular relaxation velocity; A' = annular velocity during auricular contraction; $S^{\prime}=$ annular velocity during ventricular systole; MPI' = myocardial performance index measured by TDI. 
Table 3. Summary of most relevant color tissue Doppler studies

\begin{tabular}{|c|c|c|c|c|c|c|c|c|}
\hline Reference & $\begin{array}{l}\text { Echocardio- } \\
\text { graphic system }\end{array}$ & $\begin{array}{l}\text { Sample } \\
\text { size }\end{array}$ & Population & $\begin{array}{l}\text { GA } \\
\text { range } \\
\text { weeks }\end{array}$ & Locations & $\begin{array}{l}\text { Frame } \\
\text { rate }\end{array}$ & Results & Limitations \\
\hline $\begin{array}{l}\text { Paladini et } \\
\text { al. [16] (2000) }\end{array}$ & $\begin{array}{l}\text { Toshiba } \\
\text { Powervision }\end{array}$ & 89 & $\begin{array}{l}\text { Normal } \\
\text { fetuses }\end{array}$ & $17-37$ & $\begin{array}{l}\text { Left and right } \\
\text { ventricular walls }\end{array}$ & $20-40$ & $\begin{array}{l}\text { PAV increased with GA. } \\
\text { E'/A' was constant during } \\
\text { gestation. Subendocardial } \\
\text { velocities were higher than } \\
\text { subepicardial velocities. }\end{array}$ & $\begin{array}{l}\text { Low frame rate. } \\
\text { Use of a transverse } \\
\text { four-chamber view. }\end{array}$ \\
\hline $\begin{array}{l}\text { Rein et al. } \\
\text { [35] (2002) }\end{array}$ & GE Vivid-5 & 31 & $\begin{array}{l}\text { Fetal } \\
\text { arrhythmia }\end{array}$ & $18-38$ & $\begin{array}{l}\text { Left and right } \\
\text { atrial wall and } \\
\text { annulus }\end{array}$ & $48-136$ & $\begin{array}{l}\text { TDI could be useful in the } \\
\text { evaluation of } \\
\text { supraventricular and } \\
\text { ventricular arrhythmias. }\end{array}$ & $\begin{array}{l}\text { Low frame rate. Diagnosis } \\
\text { of the arrhythmia could not } \\
\text { always be confirmed after } \\
\text { birth. }\end{array}$ \\
\hline $\begin{array}{l}\text { Di Salvo et } \\
\text { al. [23] (2005) }\end{array}$ & GE Vivid-7 & 75 & $\begin{array}{l}\text { Normal } \\
\text { fetuses }\end{array}$ & $21-29$ & $\begin{array}{l}\text { Mid wall } \\
\text { (left, right, } \\
\text { and septum) }\end{array}$ & $40-90$ & $\begin{array}{l}\text { Longitudinal myocardial } \\
\text { deformation properties } \\
\text { increased with GA and are } \\
\text { homogeneous in left and } \\
\text { right ventricles. }\end{array}$ & $\begin{array}{l}\text { Limited reproducibility of } \\
\text { S and SR. }\end{array}$ \\
\hline $\begin{array}{l}\text { Nii et al. [17] } \\
\text { (2006) }\end{array}$ & GE Vivid-7 & 114 & $\begin{array}{l}\text { Normal } \\
\text { fetuses }\end{array}$ & $14-42$ & $\begin{array}{l}\text { Annulus } \\
\text { (left, right, } \\
\text { and septum) }\end{array}$ & $230 \pm 28$ & $\begin{array}{l}\text { E', A', and E'/A' increased } \\
\text { with GA. E/E' decreased } \\
\text { with GA and remained } \\
\text { stable in the third trimester. }\end{array}$ & $\begin{array}{l}\text { C-TDI velocities were lower } \\
\text { than previously published } \\
\text { S-TDI velocities. }\end{array}$ \\
\hline $\begin{array}{l}\text { Larsen et al. } \\
\text { [19] (2006) }\end{array}$ & GE Vivid-7 & 4 & $\begin{array}{l}1 \text { aortic atresia, } \\
3 \text { normal fetuses }\end{array}$ & $19-36$ & $\begin{array}{l}\text { Annulus } \\
\text { (left, right, } \\
\text { and septum) }\end{array}$ & $170-216$ & $\begin{array}{l}\text { Reduced left and septal } \\
\text { SR in the fetus with aortic } \\
\text { atresia. }\end{array}$ & Small sample size. \\
\hline $\begin{array}{l}\text { Perles et al. } \\
{[18](2007)}\end{array}$ & GE Vivid-5 & 98 & $\begin{array}{l}\text { Normal } \\
\text { fetuses }\end{array}$ & $13-40$ & $\begin{array}{l}\text { Left and right } \\
\text { annulus }\end{array}$ & $105-212$ & $\begin{array}{l}\text { PAV increased with GA. } \\
\text { S and SR were constant } \\
\text { throughout gestation. }\end{array}$ & \\
\hline $\begin{array}{l}\text { Larsen et al. } \\
\text { [27] (2009) }\end{array}$ & GE Vivid-7 & 62 & $\begin{array}{l}20 \text { IUGR } \\
42 \text { controls }\end{array}$ & $26-34$ & $\begin{array}{l}\text { Left and right } \\
\text { annulus }\end{array}$ & $175-215$ & $\begin{array}{l}\text { Lower left } S^{\prime} \text { in IUGR. } \\
\text { Left } S \text { ' and revered UA } \\
\text { flow was associated with } \\
\text { perinatal death. }\end{array}$ & $\begin{array}{l}\text { Small subdivision groups } \\
\text { by flow class. }\end{array}$ \\
\hline $\begin{array}{l}\text { Di Naro et } \\
\text { al. [34] } \\
(2010)\end{array}$ & $\begin{array}{l}\text { Aloka } \\
\text { Prosound } \\
\text { Alpha } 10\end{array}$ & 39 & $\begin{array}{l}12 \text { PPROM, } \\
27 \text { controls }\end{array}$ & $24-34$ & $\begin{array}{l}\text { Right annulus } \\
\text { (velocity) and } \\
\text { right ventricular } \\
\text { wall (S and SR) }\end{array}$ & $\begin{array}{l}\text { Not } \\
\text { speci- } \\
\text { fied }\end{array}$ & $\begin{array}{l}\text { Higher E'/A' and early } \\
\text { diastolic SR, lower systolic } \\
\text { S and systolic SR in } \\
\text { PPROM. }\end{array}$ & Small sample size. \\
\hline $\begin{array}{l}\text { Larsen et al. } \\
\text { [28] (2011) }\end{array}$ & GE Vivid-7 & 53 & $\begin{array}{l}15 \text { IUGR } \\
42 \text { controls }\end{array}$ & $24-34$ & $\begin{array}{l}\text { Left and right } \\
\text { annulus }\end{array}$ & $175-215$ & $\begin{array}{l}\text { Lower left and right A' and } \\
\text { higher left E'/A' in IUGR. }\end{array}$ & $\begin{array}{l}\text { Small sample size. Some } \\
\text { fetuses had sequential } \\
\text { examinations and others } \\
\text { not. }\end{array}$ \\
\hline
\end{tabular}

Frame rates are expressed as ranges or means $\pm \mathrm{SD}$. GA = Gestational age; E' = early diastolic annular relaxation velocity; $\mathrm{A}^{\prime}=$ annular velocity during auricular contraction; $S^{\prime}=$ annular velocity during ventricular systole; PPROM = preterm premature rupture of membranes.

\section{Clinical Applications of TDI in Fetuses}

In recent years, tissue Doppler studies have emerged to evaluate fetal cardiac function in several clinical conditions. Due to the higher sensitivity of this technique, TDI can be useful to detect cardiac dysfunction alone or in combination with conventional Doppler. The most important tissue Doppler studies are summarized in tables 2 and 3.
Intrauterine growth restriction (IUGR) has been clearly associated with cardiac dysfunction, explained by the major role of the heart as the central organ in fetal adaptive mechanisms to placental insufficiency. Several studies have demonstrated systolic and diastolic cardiac dysfunction in growth-restricted fetuses using S-TDI and C-TDI: decreased PAV [13, 27, 28], increased E'/A' ratios $[13,28,29]$, decreased E/E' ratios [29], and higher values of MPI' [13]. The decrease in systolic peak velocities has 
been proposed as a predictor of perinatal mortality in IUGR fetuses with reversed umbilical artery [27]. Changes in tissue Doppler parameters, with regards to PAV and MPI', have also been described in small-for-gestationalage (SGA) fetuses with a normal umbilical artery. In contrast with conventional echocardiography, TDI could detect significant differences between SGA fetuses and controls, supporting the higher sensitivity of this technique in detecting subclinical fetal cardiac dysfunction [30].

Maternal diabetes is the most common cause of fetal hypertrophic cardiomyopathy [31,32]. Cardiac hypertrophy is reflected by increased values of PAV and leads to diastolic dysfunction measured by increased E'/A' and decreased E/E' ratios [33].

Changes in deformation parameters have been described in fetuses with preterm premature rupture of membranes and proven intraamniotic infection. Right ventricular function was evaluated in these fetuses using C-TDI and signs of diastolic and systolic dysfunction were demonstrated, characterized by increased E'/A', increased early diastolic SR, reduced systolic SR, and longitudinal myocardial dyskinesia [34].

Another potential application of C-TDI during fetal life is in the diagnosis and understanding of fetal arrythmias. Rein et al. [35] described a new method that allows simultaneous sampling of the right and left atrial and ventricular wall velocities to acquire temporal analysis of atrial and ventricular events. However, the low frame $(48-136 \mathrm{~Hz})$ used in this work strongly limits its validity.

Finally, fetuses with heart failure showed increased values of E/E' ratios and MPI' [36]. The transmitral to mitral annular diastolic velocity ratio (E/E') consists of the quotient between peak velocity during early diastole using conventional echocardiography and peak myocardial velocity during early diastole using TDI. This parameter was reported to correlate well with ventricular filling pressure [37] in adulthood. However, its value in fetal echocardiography is still unknown as no validation studies have demonstrated its significance and utility. Increased and decreased values of the E/E' ratio have been reported in altered fetal conditions, which supports the unknown value of this parameter in fetal life.

\section{Conclusions}

Tissue Doppler techniques represent a feasible method to evaluate fetal cardiac function. Reference ranges for TDI parameters have been reported for S-TDI and some clinical applications have recently been developed.

Tissue Doppler techniques were first designed to evaluate the adult heart, and their application in fetuses still has some limitations. The most important limitations are closely related to fetal characteristics during cardiac examination such as a variable position, fetal and respiratory movements, a higher heart rate, and the fact that simultaneous ECG cannot be performed. Although STDI requires formal training and special care with the angle of acquisition and the absence of fetal movements, in experienced hands, this technique is feasible and reproducible. However, these limitations are especially critical with the use of C-TDI because of the offline analysis. Application of C-TDI techniques requires further validation in fetuses and the establishment of normal references for deformation parameters. For example, the recently described decrease in $S$ with gestational age needs to be corroborated. Therefore, studies using TDI should accurately describe the methodology used for the validity and applicability of this technique to be assessed.

Despite its technical limitations, in the future, TDI could constitute a promising and sensitive method to evaluate fetal cardiac function in several clinical conditions such as IUGR, maternal diabetes, and congenital heart diseases.

\section{Acknowledgements}

This study was supported by grants from Instituto de Salud Carlos III (PI11/00051) cofinanciado por el Fondo Europeo de Desarrollo Regional de la Unión Europea Una manera de hacer Europa, Spain; Centro para el Desarrollo Técnico Industrial (cvREMOD 2009-2012) apoyado por el Ministerio de Economia y Competitividad y Fondo de inversión local para el empleo, Spain; Ministerio de Economia y Competitividad PN de I+D+I 20082011 (SAF2009-08815), Spain; Cerebra Foundation for the Brain Injured Child (Carmarthen, Wales, UK) and Thrasher Research Fund (Salt Lake City, Utah, USA).

References

Fetal Diagn Ther 2012;32:30-38
1 Isaaz K, Thompson A, Ethevenot G, Cloez JL, Brembilla B, Pernot C: Doppler echocardiographic measurement of low velocity motion of the left ventricular posterior wall. Am J Cardiol 1989;64:66-75.

- Waggoner AD, Biering SM: Tissue Doppler imaging: a useful echocardiographic method for the cardiac sonographer to assess systolic and diastolic ventricular function. J Am Soc Echocardiogr 2001;14:1143-1152.

-3 Price DJ, Wallbridge DR, Stewart MJ: Tissue Doppler imaging: current and potential clinical applications. Heart 2000;84:II11-II18. 
-4 Yu CM, Sanderson JE, Marwick TH, Oh JK: Tissue Doppler imaging a new prognosticator for cardiovascular diseases. J Am Coll Cardiol 2007;49:1903-1914.

5 Ho CY, Solomon SD: A clinician's guide to tissue Doppler imaging. Circulation 2006; 113:e396-e398.

66 Ohte N, Narita H, Hashimoto T, Akita S, Kurokawa K, Fujinami T: Evaluation of left ventricular early diastolic performance by color tissue Doppler imaging of the mitral annulus. Am J Cardiol 1998;82:1414-1417.

7 Harada K, Tsuda A, Tomomi O, Tanaka T, Takada G: Tissue Doppler imaging in the normal fetus. Int J Cardiol 1999;71:227-234.

$\checkmark 8$ Huhta JC, Kales E, Casbohm A: Fetal tissue Doppler, a new technique for perinatal cardiology. Curr Opin Pediatr 2003;15:472-474.

-9 Tutschek B, Zimmermann T, Buck T, Bender HG: Fetal tissue Doppler echocardiography: detection rates of cardiac structures and quantitative assessment of the fetal heart. Ultrasound Obstet Gynecol 2003;21:26-32.

$\checkmark 10$ Chan LY, Fok WY, Wong JT, Yu CM, Leung TN, Lau TK: Reference charts of gestationspecific tissue Doppler imaging indices of systolic and diastolic functions in the normal fetal heart. Am Heart J 2005;150:750-755.

-11 Gardiner HM, Pasquini L, Wolfenden J, Barlow A, Li W, Kulinskaya E, Henein M: Myocardial tissue Doppler and long axis function in the fetal heart. Int J Cardiol 2006;113:3947.

-12 Comas M, Crispi F, Gómez O, Puerto B, Figueras F, Gratacós E: Gestational age- and estimated fetal weight-adjusted reference ranges for myocardial tissue Doppler indices at 24-41 weeks' gestation. Ultrasound $\mathrm{Ob}$ stet Gynecol 2011;37:57-64.

$\checkmark 13$ Comas M, Crispi F, Cruz-Martinez R, Martinez JM, Figueras F, Gratacós E: Usefulness of myocardial tissue Doppler vs conventional echocardiography in the evaluation of cardiac dysfunction in early-onset intrauterine growth restriction. Am J Obstet Gynecol 2010;203:45.e1-45.e7.

- 14 Acharya G, Pavlovic M, Ewing L, Nollmann D, Leshko J, Huhta JC: Comparison between pulsed-wave Doppler and tissue Doppler-derived Tei indices in fetuses with and without congenital heart disease. Ultrasound Obstet Gynecol 2008;31:406-411.

15 Dandel M, Lehmkuhl H, Knosalla C, Suramelashvili N, Hetzer R: Strain and strain rate imaging by echocardiography - basic concepts and clinical applicability. Curr Cardiol Rev 2009;5:133-148.

-16 Paladini D, Lamberti A, Teodoro A, Arienzo M, Tartaglione A, Martinelli P: Tissue Doppler imaging of the fetal heart. Ultrasound Obstet Gynecol 2000;16:530-535.
17 Nii M, Roman KS, Kingdom J, Redington AN, Jaeggi ET: Assessment of the evolution of normal fetal diastolic function during mid and late gestation by spectral Doppler tissue echocardiography. J Am Soc Echocardiogr 2006; 19:1431-1437.

18 Perles Z, Nir A, Gavri S, Rein AJ: Assessment of fetal myocardial performance using myocardial deformation analysis. Am J Cardiol 2007;99:993-996.

19 Larsen LU, Petersen OB, Norrild K, Sorensen K, Uldbjerg N, Sloth E: Strain rate derived from color Doppler myocardial imaging for assessment of fetal cardiac function. Ultrasound Obstet Gynecol 2006;27:210-213.

20 Crispi F, Sepulveda-Swatson E, Rojas-Benavente J, Cruz-Lemini M, Valenzuela-Alcaraz B, Garcia-Posadas R, Sitges M, Bijnens B, Gratacós E: Feasibility and reproducibility of strain and strain-rate analysis of the fetal heart by tissue Doppler and 2D-speckle tracking imaging. Fetal Diagn Ther, in press.

21 Dénes M, Farkas K, Erdei T, Lengyel M: Comparison of tissue Doppler velocities obtained by different types of echocardiography systems: are they compatible? Echocardiography 2010;27:230-235.

22 Nii M, Hamilton RM, Fenwick L, Kingdom JC, Roman KS, Jaeggi ET: Assessment of fetal atrioventricular time intervals by tissue Doppler and pulse Doppler echocardiography: normal values and correlation with fetal electrocardiography. Heart 2006;92:18311837.

23 Di Salvo G, Russo MG, Paladini D, Pacileo G, Felicetti M, Ricci C, Cardaropoli D, Palma M, Caso P, Calabro R: Quantification of regional left and right ventricular longitudinal function in 75 normal fetuses using ultrasound-based strain rate and strain imaging. Ultrasound Med Biol 2005;31:1159-1162.

24 Younoszai AK, Saudek DE, Emery SP, Thomas JD: Evaluation of myocardial mechanics in the fetus by velocity vector imaging. J Am Soc Echocardiogr 2008;21:470-474.

-25 Matsui H, Germanakis I, Kulinskaya E, Gardiner HM: Temporal and spatial performance of vector velocity imaging in the human fetal heart. Ultrasound Obstet Gynecol 2011;37:150-157.

26 Willruth AM, Geipel AK, Fimmers R, Gembruch UG: Assessment of right ventricular global and regional longitudinal peak systolic strain, strain rate and velocity in healthy fetuses and impact of gestational age using a novel speckle/feature-tracking based algorithm. Ultrasound Obstet Gynecol 2011;37: 143-149.

27 Larsen LU, Sloth E, Petersen OB, Pedersen TF, Sorensen K, Uldbjerg N: Systolic myocardial velocity alterations in the growth-restricted fetus with cerebroplacental redistribution. Ultrasound Obstet Gynecol 2009;34: 62-67.
28 Larsen LU, Petersen OB, Sloth E, Uldbjerg N: Color Doppler myocardial imaging demonstrates reduced diastolic tissue velocity in growth retarded fetuses with flow redistribution. Eur J Obstet Gynecol Reprod Biol 2011;155:140-145.

29 Naujorks AA, Zielinsky P, Beltrame PA, Castagna RC, Petracco R, Busato A, Nicoloso AL, Piccoli A, Manica JL: Myocardial tissue Doppler assessment of diastolic function in the growth-restricted fetus. Ultrasound Obstet Gynecol 2009;34:68-73.

30 Comas M, Crispi F, Cruz-Martinez R, Figueras F, Gratacós E: Tissue-Doppler echocardiographic markers of cardiac dysfunction in small-for-gestational age fetuses. Am J Obstet Gynecol 2011;205:57.e1-57.e6.

- 31 Gardiner HM, Pasquini L, Wolfenden J, Kulinskaya E, Li W, Henein M: Increased periconceptual maternal glycated haemoglobin in diabetic mothers reduces fetal long axis cardiac function. Heart 2006;92:1125-1130.

32 Gandhi JA, Zhang XY, Maidman JE: Fetal cardiac hypertrophy and cardiac function in diabetic pregnancies. Am J Obstet Gynecol 1995;173:1132-1136.

33 Hatém MA, Zielinsky P, Hatém DM, Nicoloso LH, Manica JL, Piccoli AL, Zanettini Oliveira V, Scarpa F, Petracco R: Assessment of diastolic ventricular function fetuses of diabetic mothers using tissue Doppler. Cardiol Young 2008; 18:297-302.

34 Di Naro E, Cromi A, Ghezzi F, Giocolano A, Caringella A, Loverro G: Myocardial dysfunction in fetuses exposed to intraamniotic infection: new insights from tissue Doppler and strain imaging. Am J Obstet Gynecol 2010;203:459.e1-459.e7.

35 Rein AJ, O’Donnell C, Geva T, Nir A, Perles Z, Hashimoto I, Li XK, Sahn DJ: Use of tissue velocity imaging in the diagnosis of fetal cardiac arrhythmias. Circulation 2002;106: 1827-1833.

36 Aoki M, Harada K, Ogawa M, Tanaka T: Quantitative assessment of right ventricular function using doppler tissue imaging in fetuses with and without heart failure. J Am Soc Echocardiogr 2004;17:28-35.

37 Duzenli MA, Ozdemir K, Aygul N, Soylu A, Aygul MU, Gök H: Comparison of myocardial performance index obtained either by conventional echocardiography or tissue Doppler echocardiography in healthy subjects and patients with heart failure. Heart Vessels 2009;24:8-15.

38 Watanabe S, Hashimoto I, Saito K, Watanabe K, Hirono K, Uese K, Ichida F, Saito S, Miyawaki T, Niemann P, Sahn DJ: Characterization of ventricular myocardial performance in the fetus by tissue Doppler imaging. Circ J 2009;73:943-947. 